\title{
Quercetin: a flavonoid with the potential to treat asthma
}

\author{
Laila Rigolin Fortunato, Claudiney de Freitas Alves, Maxelle Martins Teixeira, \\ Alexandre Paula Rogerio*
}

Laboratory of Experimental Immunopharmacology, Universidade Federal of Triângulo Mineiro

\begin{abstract}
Allergic asthma is a complex inflammatory disorder characterized by airway hyperresponsiveness, eosinophilic inflammation and hypersecretion of mucus. Current therapies include $\beta_{2}$-agonists, cysteinyl leukotriene receptor 1 antagonists and corticosteroids. Although these drugs demonstrate beneficial effects, their adverse side effects limit their long-term use. Thus, the development of new compounds with similar therapeutic activities and reduced side effects is both desirable and necessary. Natural compounds are used in some current therapies, as plant-derived metabolites can relieve disease symptoms in the same manner as allopathic medicines. Quercetin is a flavonoid that is naturally found in many fruits and vegetables and has been shown to exert multiple biological effects in experimental models, including the reduction of major symptoms of asthma: bronchial hyperactivity, mucus production and airway inflammation. In this review, we discuss results from the literature that illustrate the potential of quercetin to treat asthma and its exacerbations.
\end{abstract}

Uniterms: Quercetin. Flavonoids. Asthma.

\begin{abstract}
A asma alérgica é uma doença inflamatória complexa caracterizada por hiperresponsividade das vias aéreas, inflamação eosinofílica e hipersecreção de muco. As terapias atuais incluem $\beta_{2}$-agonistas, antagonistas do receptor 1 de cisteinil leucotrienos e corticosteróides. Embora estes fármacos demonstrem efeitos benéficos, seus efeitos adversos limitam seus usos a longo prazo. Assim, o desenvolvimento de novos compostos com atividades terapêuticas similares e reduzido efeitos adversos é tanto desejável quanto necessário. Compostos naturais podem ser utilizados nas terapias atuais, uma vez que metabólitos derivados de plantas são capazes de aliviar os sintomas de forma comparável aos medicamentos alopáticos. A quercetina é um flavonóide que ocorre naturalmente em muitas frutas e vegetais e tem mostrado vários efeitos biológicos, principalmente em modelos experimentais, incluindo a redução dos principais fenótipos da asma: hiperreatividade brônquica, produção de muco e inflamação das vias aéreas. Nesta revisão, nós discutimos os resultados da literatura que revelam o potencial da quercetina para tratar a asma e suas exacerbações.
\end{abstract}

Unitermos: Quercetina. Flavonóides. Asma.

\section{INTRODUCTION}

Asthma is a chronic inflammatory disease common worldwide (Mukherjee, Zhang, 2011). According to the guidelines issued by the U.S. National Heart, Lung and Blood Institute and the Global Initiative for Asthma (GINA), asthma severity can be classified based on clinical features into intermittent, mild persistent, moderate persistent, and severe persistent asthma (Wenzel, 2006).

*Correspondence: A. P. Rogerio. Laboratory of Experimental Immunopharmacology, Universidade Federal do Triângulo Mineiro. Rua Manoel Carlos, 162, 38025-380 - Uberaba - MG, Brazil. E-mail: alexprogerio@yahoo.com.br; alexprogerio@biomedicina.uftm.edu.br
The most common signs of asthma include airway obstruction, wheezing and airway hyperresponsiveness (Bousquet et al., 2000). In addition, patients also exhibit airway inflammation characterized by the recruitment of eosinophils and other leukocytes, airway smooth muscle hypertrophy/hyperplasia, systemic IgE production and mucus hypersecretion.

The pathophysiology of allergic asthma is mediated by $\mathrm{CD}^{+} \mathrm{T}$ cell immune responses. T helper (Th) 1 and Th17 cells promote neutrophil recruitment and have been associated with both severe and steroid-resistant asthma. Th9 cells have been shown to affect mucus production, mast cell recruitment and IgE production. $\mathrm{CD} 8^{+} \mathrm{T}$ cells, 
NKT cells and $\gamma \delta$ T cells are also able to modulate asthmaassociated inflammation and/or airway hyperresponsiveness (AHR). In contrast, Treg cells are known to suppress innate and adaptive immune responses and decrease inflammation. Although knowledge regarding the roles of different $\mathrm{T}$ cell subsets in the asthma has increased in recent years, Th2-type immune responses are most classically associated with the pathology of asthma (Lloyd, Hessel, 2010).

Asthma exacerbations are common, and their prevention and treatment are perhaps the most important clinical issues for optimal asthma control (Messer et al., 2010). Episodes of asthma exacerbation can be triggered by allergen inhalation, viruses, pollutant exposure, exercise, non-steroidal anti-inflammatory medications and occupational agents (Chua, Lai, 2007; Tillie-Leblond et al., 2005). In episodes of asthma exacerbation, in addition to eosinophils, neutrophils are recruited to the airway. In fact, neutrophils are the most prevalent inflammatory cell population in the airways of individuals who have died from asthma attacks (Sur et al., 1993).

Typical asthma treatments include $\beta_{2}$-agonists and systemic corticosteroids (Mukherjee, Zhang, 2011; NIH, 1997). Administration of nebulized $\beta_{2}$-agonists (continuous or repetitive), such as salbutamol, causes bronchodilation and is considered a first-line treatment for the management of asthma (NIH, 1997; Wort, 2003). Corticosteroids are the most commonly prescribed therapeutics for controlling nearly all types of inflammatory reactions and exert strong effects on leukocyte recruitment when administered orally or systemically (Harris, 1972; Flower, 1988; Perretti, Flower, 1993). The most striking effect of corticosteroids is their ability to inhibit the expression of multiple inflammatory mediators whose genes are regulated by transcription factors, such as nuclear factor- $\mathrm{\kappa B}$

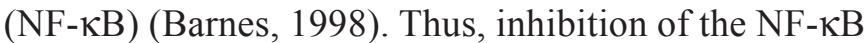
pathway is associated with decreased expression of genes encoding cytokines (e.g., IL-5), chemokines (e.g., eotaxins) and adhesion molecules (e.g., E-selectin), all of which play critical roles in regulating eosinophil recruitment (Rabier et al., 1991; Faccioli et al., 1996). Inhibitors of LT synthesis (such as zileuton, which directly inhibits 5-LO) or CysLT ${ }_{1}$ antagonists (such as montelukast, zafirlukast, and pranlukast) may also be used as complementary therapies to treat asthma, reducing the requirement for corticosteroids (Salvi et al., 2001; Peters-Golden, Henderson, 2007; Montuschi et al., 2007).

Although the drugs described above have potent effects when used individually or in combination, they also have adverse side effects that limit their long-term use (Papiris et al., 2009). Prolonged use of corticosteroids can lead to iatrogenic Cushing's syndrome, osteoporosis, susceptibility to infections, and psychiatric disorders, along with various other disorders (Macfarlane, Forbes, Walker, 2008; Dias et al., 2010). Increased cardiovascular complications in patients who use $\beta_{2}$-agonists might be the consequence of increased heart rates and reduced potassium levels (Salpeter, Ormiston, Salpeter, 2004; Cazzola, Matera, Donner, 2005). Usage of inhibitors of LT synthesis has been associated with headaches and gastrointestinal disturbances (Cung, 1995). Thus, it is necessary to develop new compounds with similar therapeutic potential and less adverse effects for the continuous treatment of airway diseases.

Agents of natural origin that induce very few side effects should be considered for therapeutic substitution or as complementary treatments. Furthermore, natural compounds may serve as the basis for new drugs in the treatment of many diseases (Verpoorte, 1999). In an ongoing search for bioactive plant-derived natural products, several groups, including ours, have successfully employed experimental methods to screen plant extracts and plant secondary metabolites for pharmacological activity. In addition, several groups have also demonstrated the effectiveness of extracts from plants, such as Ginkgo biloba and Hypericum perforatum, in clinical trials (Wadsworth et al., 2001, Canning et al., 2010).

The earliest written records on the use of medicinal plants were found in Assyrian clay tablets (2000 BC), the Egyptian Ebers Papyrus (1550 BC) and in Ayurveda works from 900 BC. Moreover, Hippocrates, Dioscorides, Galen, Paracelsus and Arab scholars in Europe preserved knowledge regarding the use of medicinal plants (Sneader, 2005; Potterat, Hamburger, 2008). The origin of researching natural products in the pharmaceutical industry began with the isolation of morphine from opium latex in 1805 by Sertürner (Potterat, Hamburger, 2008). However, the most famous product of plant origin, which was discovered the $19^{\text {th }}$ century, is acetylsalicylic acid (ASA), a derivative of salicylic acid extracted from willow bark (Salix alba and other species) (Rainsford, 2007). Patented by Bayer in 1900 and sold under the brand name Aspirin, ASA is primarily used to treat pain and inflammation.

Several plant-derived secondary metabolites can decrease the expression and production of inflammatory mediators and their receptors, down-regulate the production and activity of second messengers and inhibit the expression of transcription factors that promote the production of inflammatory molecules (Calixto et al., 2000, 2004). Such effects provide symptom relief similar to that afforded by allopathic medicines. Flavonoids are the most studied class of plant metabolites. The search term 
"flavonoids" yielded more than 57,300 entries in the U.S. National Library of Medicine's Medline database accessed using PubMed in December 2011.

Flavonoids are a family of plant compounds with a similar flavone backbone composed of two aromatic rings and an oxygen heterocycle with hydroxyl groups attached. There are many classes of flavonoids, such as flavones, flavanones, isoflavones, flavonols, flavanonols, flavan-3-ols, and anthocyanidins. Flavonoid molecules may or may not be attached to sugars. Compounds containing no sugars are known as aglycones (Pietta, 2000). The quercetin aglycone is a flavonol that occurs naturally in fruits and vegetables, including onions, apples, grapes and nuts. Therefore, it is commonly included in human diets (Middleton et al., 2000). Quercetin may have already been used in treating human disease (phytotherapy), as it is present in the seeds, stems, barks, roots and/or flowers of several medicinal plants.

Typically, quercetin is linked to sugars, such as glucose (quercetin-3-glucoside, isoquercitrin) or rutinose (rutin). However, after ingestion, enzymes in the mouth and the intestines hydrolyze quercetin glycosides to quercetin aglycones (Egert et al., 2010; Perez-Vizcaino et al., 2009). Interestingly, quercetin and its metabolites have been observed in the lungs of rats (De Boer et al., 2005). In human, quercetin metabolites have also been found to be present in the carbon dioxide $\left(\mathrm{CO}_{2}\right)$ exhaled from the lung (Walle et al., 2001).

\section{POTENTIAL EFFECTS OF QUERCETIN ON ASTHMA}

Quercetin has a wide range of therapeutic properties, including, but not limited to, its antioxidant, anti-cancer, anti-inflammatory and anti-allergic activities. Recently, key findings have been made regarding the effects of quercetin on the airway (Figure 1).

Mast cells play an important role in the early and late phases of asthma, as they release several mediators, including histamine, leukotrienes and cytokines, which modulate airway hyperreactivity and inflammation. IgE binds to mast cells and basophils through their high-affinity $\mathrm{IgEF}$ F receptor (FceRI) (Gould, Sutton, 2008; Furuichi, Rivera, Isersky, 1985), and subsequent exposure to antigen induces IgE-sensitized mast cell degranulation. During degranulation, both pre-formed and newly generated mediators are released. These mediators, either alone or in conjunction with Th2 cytokines, increase smooth muscle cell contractility, epithelial cell permeability and mucus production. Furthermore, mast cell degranulation triggers the recruitment of macrophages, eosinophils and basophils to the inflammatory site (Holgate, Polosa, 2008). Previous findings have shown that treatment with quercetin inhibits the release of histamine and pro-inflammatory mediators (TNF- $\alpha$, IL-1 $\beta$, IL-6 and IL-8) from mast cells stimulated with IgE (Cruz et al., 2012; Park et al., 2008; Kempuraj et al., 2005), likely due to inhibition of NF- $\mathrm{KB}$ and $\mathrm{p} 38$ mitogen-activated protein kinase (p38 MAPK) (Min et al., 2007). Thus, quercetin demonstrates the potential to modulate the early and late phases of asthma.

A systematic review conducted by our group showed the anti-eosinophilic effects of medicinal plants and plant-derived substances in eosinophilic models, including models of acute peritonitis induced by either the polysaccharide-rich F1 fraction from Histoplasma capsulatum yeast or by Toxocara canis helminth infection, also known as visceral larva migrans syndrome (VLMS) or toxocariasis, and the classical ovalbumin-induced allergic asthma model (Rogerio, Sá-Nunes, Faccioli, 2010). Eosinophils produce cytokines (e.g., IL-4, IL-5 and IL-13), chemokines (e.g., CCL11) (Perretti, Flower, 1993; Barnes, 1998; Barnes, 2006), lipid mediators $\left(\mathrm{LTB}_{4}\right)$ and principal cationic proteins (major basic protein, eosinophil-derived neurotoxin, eosinophil cationic protein and eosinophil peroxidase) that can exacerbate airway inflammation and cause tissue damage (Rothenberg, Hogan, 2006; Gleich, Loegering, 1984). Our group was the first to demonstrate that quercetin $(10 \mathrm{mg} / \mathrm{kg}$; oral dose) reduces eosinophils in the blood, bronchoalveolar lavage fluid (BALF) and the pulmonary parenchyma in a murine model of ovalbumininduced allergic airways inflammation (Rogerio et al., 2007). Interestingly, in this study, isoquercitrin (quercetin attached to glucose) was more efficient than quercetin aglycone in decreasing IL-5 concentrations in the BALF. IL-5 is the main cytokine involved in blood eosinophilia during both allergic inflammation and parasitic infection. This cytokine is essential for eosinophil migration from the bone marrow to the blood (Faccioli et al., 1996; Sanderson et al., 1985), and it specifically supports the terminal differentiation and proliferation of eosinophil precursors. Additionally, IL-5 activates mature eosinophils (Yamaguchi et al., 1988; Clutterbuck, Sanderson, 1988). Similar results were found by other groups employing the same experimental models in mice and guinea pigs but using different routes of quercetin administration (intraperitoneal or aerosol route) (Moon et al., 2008; Jung et al., 2007; Park et al., 2009). Quercetin has also demonstrated the potential to reduce airway hyperresponsiveness, bronchial hyperactivity (Ko et al., 2004; Jiang et al., 2007) and mucus production (Chang et al., 2010).

Despite its potential systemic anti-inflammatory property, quercetin aglycone is known to be poorly soluble 


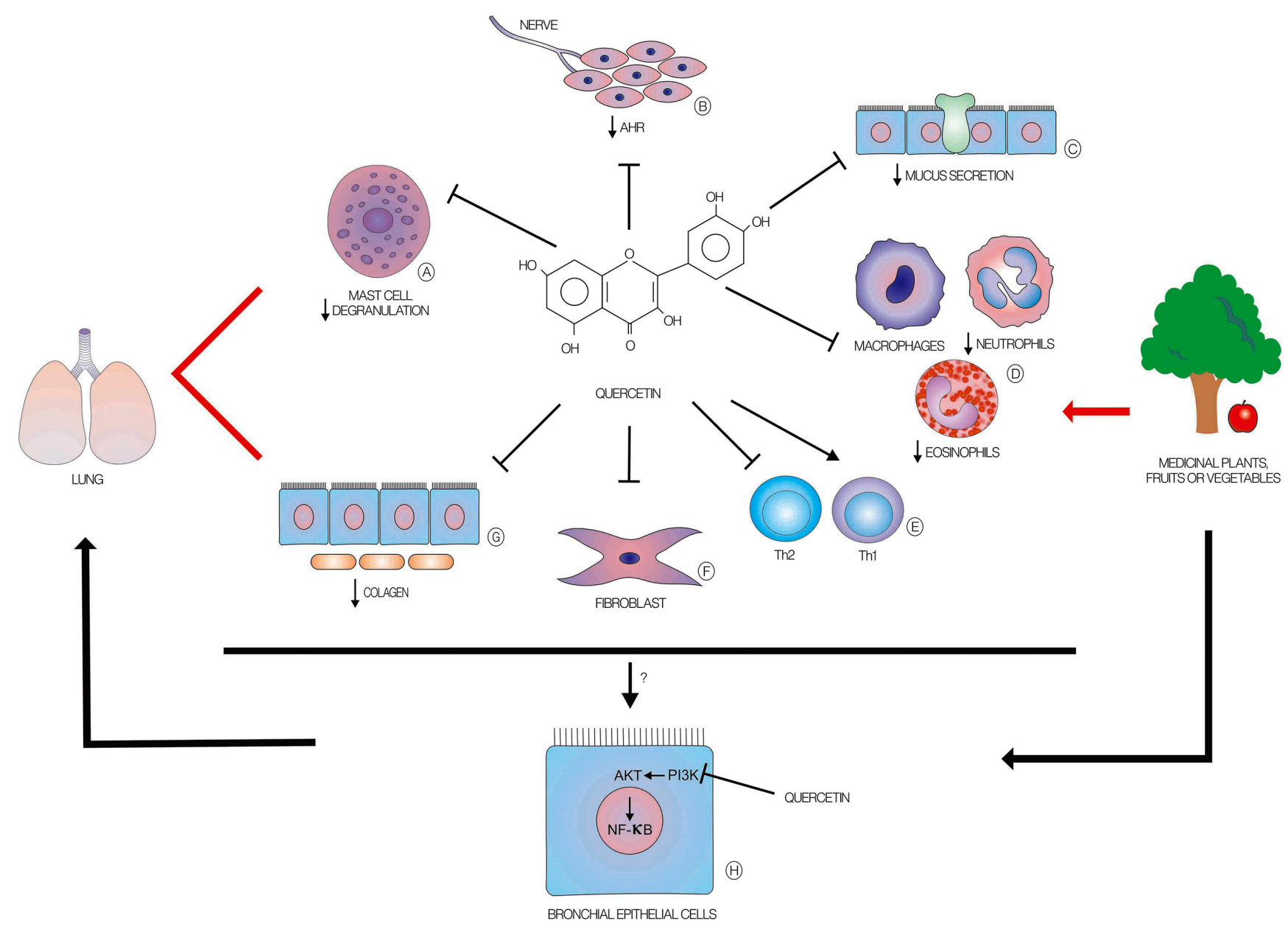

FIGURE 1 - Possible effects and mechanisms of quercetin activity during asthma. Previous findings have shown that quercetin inhibits mast cell degranulation (A), reduces airway hyperreactivity (B), reduces mucus production (C), causes decreases in eosinophil and neutrophil recruitment (D), modulates Th1/Th2 cytokine production (E), demonstrates anti-fibrotic activities (F) and reduces collagen deposition $(\mathrm{G})$. These effects might be associated with attenuation of the PI3-kinase, Akt and NF- $\mathrm{kB}$ signaling pathways $(\mathrm{H})$.

in water. Previous findings have shown that it is less absorbed than quercetin glycosides and that its absorption seems to depend on the type and position of the sugar moieties (Hollman et al., 1995; Hollman et al., 1997). In the above studies, dimethyl sulfoxide (DMSO) and polyethylene glycol were used as adjuvants to improve quercetin solubilization and absorption. However, these substances are not approved for human use.

Colloidal drug delivery systems, such as microemulsions, have been proposed to improve the absorption and therapeutic index of several drugs (Gupta et al., 2005). Microemulsions are isotropic liquid mixtures of oil, water and surfactant frequently found in combination with a co-surfactant and are translucent and thermodynamically stable. The dispersed phase, generally lipophilic, acts as a potential reservoir of lipophilic drugs that, when it contacts semi-permeable membranes, such as skin or a mucous membrane, can facilitate the transport of drugs through these barriers (Formariz et al., 2007; Vicentini et al., 2008).

In a murine model of ovalbumin-induced allergic airway inflammation, treatment with a quercetin-loaded microemulsion (QU-ME) was more effective than quercetin suspension (QU-SP) and reduced eosinophil recruitment; decreased the production of IL-4, IL-5, CCL11 and $\mathrm{LTB}_{4}$; inhibited mucus production; and down-modulated $\mathrm{P}$-selectin expression by blocking NF- $\kappa \mathrm{B}$ signaling. Under inflammatory conditions, IL-5 and the eotaxins CCL11, CCL24 and CCL26 have been shown to cooperate in selectively recruiting eosinophils (Jose et al., 1994; Rothenberg et al., 1995). IL-4 and IL-13 are potent inducers of eotaxins. Additionally, when administered exogenously, eosinophils collaborate with IL-5 to induce IL-13 production in the lungs (Zimmermann et al., 2003). $\mathrm{LTB}_{4}$, 
a lipoxygenase (LO)-derived product, is also involved in the activation and chemotaxis of eosinophils, among other cells (Peters-Golden, Henderson, 2007). Thus, the higher efficacy of QU-ME was due to the increased oral absorption of quercetin and, consequently, the reduction of cytokines, chemokines and lipid mediators involved in trafficking of eosinophils into inflammatory sites (Rogerio et al., 2010).

In the inflammation associated with asthma, the expression of multiple inflammatory mediators is regulated by transcription factors. The T-box and GATA family of transcription factors plays several roles in hematopoiesis and is active in many cell lineages, including $\mathrm{T}$ cells. While the upregulation of GATA-3 promotes Th2 cell differentiation (Barnes, 2011), the expression of T-bet is a determinant for Th1 cell differentiation (Lazarevic, Glimcher, 2011). Quercetin suppressed GATA-3 and increased T-bet expression in a murine model of ovalbumin-induced allergic airway inflammation. Consequently, quercetin reduced IL-4 and increased IFN- $\gamma$ concentration in the BALF of these animals (Park et al., 2009). IL-4 is primarily responsible for the development of Th2-type immune responses. In contrast, IFN- $\gamma$, a Th1 cytokine, inhibits Th 2 immune responses and may provide some rationale for the outcome of allergic airway inflammation (Saggini et al., 2011). These results demonstrate that quercetin is able to modulate Th1/Th2 cytokine production and consequently asthma pathology.

Currently, many questions still remain concerning the nature of the inflammatory process in severe episodes of asthma exacerbation. In addition to eosinophils, neutrophils are also important cells that release oxidative products, eicosanoids and metalloproteinases (specifically MMP-9), which contribute to lung epithelial and endothelial cell injury and increase vascular permeability. Interestingly, tissue inhibitor of metalloproteinase (TIMP)-1, an inhibitor of MMP-9, is reduced in the plasma and the bronchi of patients with asthma (Belleguic et al., 2002). In an experimental model of airway inflammation induced by the intranasal administration of elastase and LPS, quercetin inhibited neutrophil recruitment and MMP-9 and MMP-12 expression and activity both in vivo and in vitro (Ganesan et al., 2010). Taken together with other published results, these findings suggest potential beneficial effects of quercetin treatment on asthmatic airway inflammation.

The airway epithelium's function is to transport air into the alveoli and to protect the lungs against pathogens, allergens and inhaled environmental particulates through the secretion of antimicrobial molecules and pro-inflammatory cytokines and chemokines. In addition, the airway epithelium also has the ability to modulate the function of lung dendritic cells, which are essential in initiating inflammation and determining the type of effector immune response (Th1, Th2 or Th17) (Belleguic et al., 2002; Ganesan et al., 2010). Treatment with quercetin prior to TNF- $\alpha$ stimulation reduced the expression of IL-8 and chemokines (C-C motif) ligand 2 (CCL2/MCP-1) in bronchial epithelial cells (Nanua et al., 2006), which are involved in asthma pathogenesis (Romagnani, 2002). This effect was associated with attenuation of the PI3-kinase, Akt and NF- $\mathrm{KB}$ signaling pathways. Several other studies have also demonstrated this effect of quercetin on NF- $\kappa B$ reduction (Nam, 2006; Rahman, Adcock, 2006).

Adhesion molecules are involved in the control of leukocyte influx. Expression of intercellular adhesion molecule-1 (ICAM-1), an adhesion molecule that participates in cell-cell and cell-matrix adhesive interactions, has been associated with several inflammatory diseases, including asthma (Stanciu, Djukanovic, 1998). Quercetin has been shown to reduce ICAM-1 expression on a pulmonary epithelial cell line (A549) in a dose-dependent manner, and decreased ICAM-1 expression has been shown to be mediated through inhibition of the NF- $\mathrm{KB}, \mathrm{ERK}-1 / 2$ and JNK signaling pathways (Ying et al., 2009). Thus, quercetin's effect in reducing leukocyte recruitment may be associated with a reduction in chemokines and adhesion molecules. In addition to epithelial cells, fibroblasts are also involved in asthma pathogenesis.

Fibroblasts are responsible for the synthesis of collagen, with human fibroblasts synthesizing both type I and type III collagen. Repetitive injury of the alveolar-capillary membrane results in a loss of basement membrane integrity, and the subsequent activation of fibroblasts and myofibroblasts can lead to fibrosis. In the lungs, fibroblast accumulation and abnormal remodeling can result in respiratory failure (Bousquet, Yssel, Vignola, 2000). Studies have shown that quercetin exhibits potent antifibrotic effects in the lungs (Nakamura et al., 2011; Qi et al., 2001). Treatment with liposomal quercetin in a rat bleomycin-induced pulmonary fibrosis model suppressed lung hydroxyproline content and collagen deposition (Baowen et al., 2010). Quercetin also decreased type I and type III collagen synthesis in both keloid and normal fibroblasts in a dose-dependent manner (Long et al., 2006). Heme oxygenase (HO)-1, an inducible stress protein, has been suggested to confer protection in diseases associated with lung injury. Nakamura et al. (2011) demonstrated that quercetin reduced fibroblast collagen deposition by inducing HO-1 upregulation. In another study using a murine model of experimental infection with Schistosoma japonicum, quercetin inhibited liver fibrosis (Xu et al., 
2006). These results suggest that quercetin might modulate airway remodeling in asthmatic patients. Interestingly, quercetin acts as a potent bronchodilator in vitro (tracheal smooth muscle) and in vivo (guinea pigs sensitized with ovalbumin) (Joskova et al., 2011).

In humans, there is some correlation between an increased risk for several chronic diseases and a lower dietary flavonoid intake. For instance, the incidence of asthma is lower in individuals who ingested higher quantities of total flavonoids, including quercetin (Knekt et $a l ., 2002)$. Quercetin has been present in the human diet throughout the history of humanity, and it is currently used as a food additive (Harwood et al., 2007). Daily oral intake of quercetin can range from 5 to $500 \mathrm{mg}$, depending on the individual's consumption of quercetin-rich fruits and vegetables, such as tomatoes and onions. Several epidemiological studies and clinical trials as well as animal and in vitro studies have been performed to evaluate the safety of quercetin. Nearly all reports found little association between dietary quercetin consumption and an increased risk of cancer or other adverse health effects (Harwood et al., 2007; Okamoto, 2005). However, quercetin, similar to other substances, may interfere with the pharmacokinetics of other medicines, such as digoxin, which could lead to significant adverse events (Wang et al., 2004). Evidence also suggests that quercetin may reduce the bioavailability of cyclosporine, simvastatin and other drugs. Therefore, although quercetin itself causes no direct significant side effects, it may give rise to indirect side effects when used in combination with other drugs. Thus, quercetin should be administered carefully if given concomitantly with other medications. However, no interactions have been described regarding the concomitant use of quercetin with drugs, such as $\beta_{2}$-agonists and corticosteroids, that are currently used to treat asthma.

\section{CONCLUSION}

Asthma and its primary exacerbations demonstrate high morbidity, mortality and health care costs. In addition, some patients are refractory to the current therapies of $\beta_{2}$-agonists and corticosteroids, whose adverse side effects limit their long-term use. Quercetin, which has been widely consumed in the diet since the beginnings of human history, has significant biological effects with no known significant adverse side effects. Quercetin demonstrates the potential to reduce the most significant pathologies of asthma, including eosinophil and neutrophil recruitment, bronchial epithelial cell activation, mucus and collagen production and airway hyperactivity. These results, in association with the low incidence of asthma in individuals with moderate dietary intake levels of quercetin, suggest that quercetin could be used medicinally, either alone or as a complement to other drugs currently used for the treatment of asthma. Additionally, it could also be used as a nutraceutical. Thus, clinical studies must be performed to evaluate the potential of quercetin to prevent or treat episodes of asthma in human patients.

\section{LIST OF ABBREVIATIONS}

AHR: airway hyperresponsiveness

ASA: acetylsalicylic acid

BALF: bronchoalveolar lavage fluids

BC: before Christ

CCL: chemokine (C-C motif) ligand

ERK: extracellular-signal-regulated kinase

FceRI: high-affinity IgE Fc receptor

ICAM-1: intercellular adhesion molecule-1

IFN- $\gamma$ : interferon gamma

Ig: immunoglobulin

IL: interleukin

JNK: c-Jun N-terminal kinase

LPS: lipopolysaccharides

LTB $_{4}$ : leukotriene B4

MAPK: mitogen-activated protein (MAP) kinases

MCP-1: monocyte chemoattractant protein 1

MMP: matrix metalloproteinase

NF- $\kappa B$ : nuclear factor- $\kappa \mathrm{B}$

NKT: natural killer T

p38 MAPK: P38 mitogen-activated protein kinase

$\mathrm{PaCO}_{2}$ : pressure of carbon dioxide

PI3K: phosphatidylinositol (PI) 3-kinase

QU-ME: quercetin-loaded microemulsion

QU-SP: quercetin suspension

Th: T helper

TIMP: tissue inhibitor of metalloproteinase

TNF- $\alpha$ : tumour necrosis factor alpha

Treg: T regulatory cell

\section{REFERENCES}

BAOWEN, Q.; YULIN, Z.; XIN, W.; WENJING, X.; HAO, Z.; ZHIZHI, C.; XINGMEI, D.; XIA, Z.; YUQUAN, W.; LIJUAN, C. A further investigation concerning correlation between anti-fibrotic effect of liposomal quercetin and inflammatory cytokines in pulmonary fibrosis. Eur. $J$. Pharmacol., v.642, n.1-3, p.134-139, 2010.

BARNES, P.J. Anti-inflammatory actions of glucocorticoids: molecular mechanisms. Clin. Sci., v.94, n.6, p.557-572, 1998. 
BARNES, P.J. How corticosteroids control inflammation: quintiles prize lecture 2005. Br. J. Pharmacol., v.148, n.3, p.245-254, 2006.

BARNES, P.J. Pathophysiology of allergic inflammation. Immunol. Rev., v.242, n.1, p.31-50, 2011.

BELLEGUIC, C.; CORBEL, M.; GERMAIN, N.; LÉNA, H.; BOICHOT, E.; DELAVAL, P.H.; LAGENTE, V. Increased release of matrix metalloproteinase- 9 in the plasma of acute severe asthmatic patients. Clin. Exp. Allergy, v.32, n.2, p.217-223, 2002.

BÉRAUD, C.; HENZEL, W.J.; BAEUERLE, P.A. Involvement of regulatory and catalytic subunits of phosphoinositide 3-kinase in NF-kappa B activation. Proc. Natl. Acad. Sci. USA, v.96, n.2, p.429-434, 1999.

BOUSQUET, J.; JEFFERY, P.K.; BUSSE, W.W.; JOHNSON, M.; VIGNOLA, A.M. Asthma: from bronchoconstriction to airways inflammation and remodeling. Am. J. Respir. Crit. Care Med., v.161, n.5, p.1720-1745, 2000.

BOUSQUET, J.; YSSEL, H.; VIGNOLA, A.M. Is allergic asthma associated with delayed fetal maturation or the persistence of conserved fetal genes? Allergy, v.55, n.12, p.1194-1197, 2000.

CALIXTO, J.B.; BEIRITH, A.; FERREIRA, J.; SANTOS, A.R.; FILHO, V.C.; YUNES, R.A. Naturally occurring antinociceptive substances from plants. Phytother. Res., v.14, n.6, p.401-418, 2000.

CALIXTO, J.B.; CAMPOS, M.M.; OTUKI, M.F.; SANTOS, A.R. Anti-inflammatory compounds of plant origin. Part II. Modulation of pro-inflammatory cytokines, chemokines and adhesion molecules. Planta Med., v.69, n.2, p.973-983, 2004.

CANNING, S.; WATERMAN, M.; ORSI, N.; AYRES, J.; SIMPSON, N.; DYE, L. The efficacy of Hypericum perforatum (St John's wort) for the treatment of premenstrual syndrome: a randomized, double-blind, placebo-controlled trial. CNS Drugs, v.24, n.3, p.207-225, 2010.

CAZZOLA, M.; MATERA, M.G.; DONNER, C.F. Inhaled beta2-adrenoceptor agonists: cardiovascular safety in patients with obstructive lung disease. Drugs, v.65, n.12, p.1595-1610, 2005.
CHANG, J.H.; SONG, K.J.; KIM, H.J.; KIM, J.H.; KIM, N.H.; KIM, K.S. Dietary polyphenols affect MUC5AC expression and ciliary movement in respiratory cells and nasal mucosa. Am. J. Rhinol. Allergy, v.24, n.2, p.59-62, 2010.

CHUA, F.; LAI, D. Acute severe asthma: Triage, treatment and thereafter current. Current Anaesthesia \& Critical Care, v.18, n.2, p.61-68, 2007.

CLUTTERBUCK, E.J.; SANDERSON, C.J. Human eosinophil hematopoiesis studied in vitro by means of murine eosinophil differentiation factor [IL5]: production of functionally active eosinophils from normal human bone marrow. Blood, v.71, n.3, p.646-651, 1988.

CRUZ, E.A.; REUTER, S.; MARTIN, H.; DEHZAD, N.; MUZITANO, M.F.; COSTA, S.S.; ROSSI-BERGMANN, B.; STASSEN, M.; TAUBE, C. Kalanchoe pinnata inhibits mast cell activation and prevents allergic airway disease. Phytomed., v.19, n.2, p.115-121, 2012.

DE BOER, V.C.; DIHAL, A.A.; VAN DER WOUDE, H.; ARTS, I.C.; WOLFFRAM, G.M.; ALINK, G.M.; RIETJENS, I.M.; KEIJER, J.; HOLLMAN, P.C. Tissue distribution of quercetin in rats and pigs. J. Nutr., v.135, n.7, p.1718-1725, 2005.

DIAS, R.P.; KUMARAN, A.; CHAN, L.F.; MARTIN, L.; AFSHAR, F.; MATSON, M.; PLOWMAN, P.N.; MONSON, J.P; BESSER, G.M.; GROSSMAN, A.B.; SAVAGE, M.O.; STORR, H.L. Diagnosis, management and therapeutic outcome in prepubertal Cushing's disease. Eur. J. Endocrinol., v.162, p.603-609, 2010.

EGERT, S.; BOESCH-SAADATMANDI, C.; WOLFFRAM, S.; RIMBACH, G.; MULLER M.J. Serum lipid and blood pressure responses to quercetin vary in overweight patients by apolipoprotein e genotype. J. Nutr., v.140, n.2, p.278284, 2010.

FACCIOLI, L.H.; MOKWA, V.F.; SILVA C.L.; ROCHA, G.M.; ARAUJO, J.I.; NAHORI, M.A.; VARGAFTIG, B.B. IL- 5 drives eosinophils from bone marrow to blood and tissues in a guinea-pig model of visceral larva migrans syndrome. Mediators Inflamm., v.5, n.1, p.24-31, 1996.

FLOWER, R.J. Eleventh Gaddum memorial lecture. Lipocortin and the mechanism of action of the glucocorticoids. Br. J. Pharmacol., v.94, n.4, p.987-1015, 1988. 
FORMARIZ, T.P.; CHIAVACCI, L.A.; SARMENTO, V.H.V.; SANTILLI, C.V.; TABOSA DO EGITO, E.S.; OLIVEIRA, A.G. Relationship between structural features and in vitro release of doxorubicin from biocompatible anionic microemulsion. Colloids Surf. B Biointerface, v.60, n.1, p.28-35, 2007.

FURUICHI, K.; RIVERA, J.; ISERSKY, C. The receptor for immunoglobulin E on rat basophilic leukemia cells: Effect of ligand binding on receptor expression. Proc. Natl. Acad. Sci. USA, v.82, n.5, p.1522-1525, 1985.

GANESAN, S.; FARIS, A.N.; COMSTOCK, A.T.; CHATTORAJ, S.S.; CHATTORAJ, A.; BURGESS, J.R.; CURTIS, J.L.; MARTINEZ, F.J.; ZICK, S.; HERSHENSON, M.B.; SAJJAN, U.S. Quercetin prevents progression of disease in elastase/LPS-exposed mice by negatively regulating MMP expression. Respir. Res., v.11, n.1, p.131-146, 2010.

GLEICH, G.J.; LOEGERING, D.A. Immunobiology of eosinophils. Annu. Rev. Immunol., v.2, p.429-445, 1984.

GOULD, H.J.; SUTTON, B.J. IgE in allergy and asthma today. Nat. Rev. Immunol, v.8, n.3, p.205-217, 2008.

GUPTA, S.; MOULIK, S.P.; LALA, S.; BASU, M.K.; SANYAL, S.K.; DATTA, S. Designing and testing of an effective oilin-water microemulsion drug delivery system for in vivo application. Drug Deliv., v.12, n.5, p.267-273, 2005.

HARRIS, L. Comparison of the effect on blood gases, ventilation, and perfusion of isoproterenol-phenylephrine and salbutamol aerosols in chronic bronchitis with asthma. J. Allergy Clin. Immunol., v.49, n.2, p.63-71, 1972.

HARWOOD, M.; D ANIELEW S KA - NIKIEL, B .; BORZELLECA, J.F.; FLAMM, G.W.; WILLIAMS, G.M.; LINES, T.C. A critical review of the data related to the safety of quercetin and lack of evidence of in vivo toxicity, including lack of genotoxic/carcinogenic properties. Food Chem. Toxicol., v.45, n.11, p.2179-2205, 2007.

HOLGATE, S.T.; POLOSA, R. Treatment strategies for allergy and asthma. Nat. Rev. Immunol., v.8, n.3, p.218-230, 2008.

HOLLMAN, P.C.; DE VRIES, J.H.; VAN LEEUWEN, S.D.; MENGELERS, M.J.; KATAN, M.B. Absorption of dietary quercetin glycosides and quercetin in healthy ileostomy volunteers. Am. J. Clin. Nutr., v.62, n.6, p.1276-1282, 1995.
HOLLMAN, P.C.; VAN TRIJP, J.M.; BUYSMAN, M.N.; VAN DER GAAG, M.S.; MENGELERS, M.J.; DE VRIES, J.H.; KATAN, M.B. Relative bioavailability of the antioxidant flavonoid quercetin from various foods in man. FEBS Lett., v.418, n.1-2, p.152-156, 1997.

JIANG, J.S.; CHIEN, H.C.; CHEN, C.M.; LIN, C.N.; KO, W.C. Potent suppressive effects of 3-O-methylquercetin 5,7,3',4'-O-tetraacetate on ovalbumin-induced airway hyperresponsiveness. Planta Med., v.73, n.11, p.1156-1162, 2007.

JOSE, P.J.; GRIFFITHS-JOHNSON, D.A.; COLLINS, P.D.; WALSH, D.T.; MOQBEL, R.; TOTTY, N.F.; TRUONG, O.; HSUAN, J.J.; WILLIAMS, T.J. Eotaxin: a potent eosinophil chemoattractant cytokine detected in a guinea pig model of allergic airways inflammation. J. Exp. Med., v.179, n.3, p.881-887, 1994.

JOSKOVA, M.; FRANOVA, S.; SADLONOVA, V. Acute bronchodilator effect of quercetin in experimental allergic asthma. Bratisl. Lek. Listy, v.112, n.1, p.9-12, 2011.

JUNG, C.H.; LEE, J.Y.; CHO, C.H.; KIM, C.J. Anti-asthmatic action of quercetin and rutin in conscious guinea-pigs challenged with aerosolized ovalbumin. Arch. Pharm. Res., v.30, n.12, p.1599-1607, 2007.

KEMPURAJ, D.; MADHAPPAN, B.; CHRISTODOULOU, S.; BOUCHER, W.; CAO, J.; PAPADOPOULOU, N.; CETRULO, C.L.; THEOHARIDES T.C. Flavonols inhibit proinflammatory mediator release, intracellular calcium ion levels and protein kinase $\mathrm{C}$ theta phosphorylation in human mast cells. Br. J. Pharmacol., v.145, n.7, p.934-944, 2005.

KNEKT, P.; KUMPULAINEN, J.; JÄRVINEN, R.; RISSANEN, H.; HELIÖVAARA, M.; REUNANEN, A.; HAKULINEN, T.; AROMAA, A. Flavonoid intake and risk of chronic diseases. Am. J. Clin. Nutr., v.76, n.3, p.560-568, 2002.

KO, W.C.; SHIH, C.M.; CHEN, M.C.; LAI, Y.H.; CHEN, J.H.; CHEN, C.M.; LIN, C.N. Suppressive effects of 3-O-methylquercetin on ovalbumin-induced airway hyperresponsiveness. Planta Med., v.70, n.12, p.1123$1127,2004$.

LAZAREVIC, V.; GLIMCHER, L.H. T-bet in disease. Nat. Immunol., v.12, n.7, p.597-606, 2011. 
LLOYD, C.M.; HESSEL, E.M. Functions of T cells in asthma: more than just Th2 cells. Nat. Rev. Immunol., v.10, n.12, p.838-848, 2010.

LONG, X.; ZENG, X.; ZHANG, F.Q.; WANG, X.J. Influence of quercetin and $\mathrm{X}$-ray on collagen synthesis of cultured human keloid-derived fibroblasts. Chin. Med. Sci. J., v.21, n.3, p.179-183, 2006.

MACFARLANE, D.P.; FORBES, S.; WALKER, B.R. Glucocorticoids and fatty acid metabolism in humans: fuelling fat redistribution in the metabolic syndrome. $J$. Endocrinol., v.197, n.2, p.189-204, 2008.

\section{MADRID, L.V.; MAYO, M.W.; REUTHER, J.Y.; BALDWIN} JR, A.S. Akt stimulates the transactivation potential of the RelA/p65 subunit of NF-kappa B through utilization of the I kappa B kinase and activation of the mitogen-activated protein kinase p38. J. Biol. Chem., v.276, n.22, p.1893418940, 2001.

MESSER, J.; PETERS, G.A.; BENNET, W.A. Cause of death and pathological findings in 304 cases of bronchial asthma. Chest, v.38, p.616-624, 1960.

MIDDLETON, E.; CHITHAN, K.; THEOHARIDES, T.C. The effects of plant flavonoids on mammalian cells: implications for inflammation, heart disease, and cancer. Pharmacol. Rev., v.52, n.4, p.673-751, 2000.

MIN, Y.D.; CHOI, C.H.; BARK, H.; SON, H.Y.; PARK, H.H.; LEE, S.; PARK, J.W.; PARK, E.K.; SHIN, H.I.; KIM, S.H. Quercetin inhibits expression of inflammatory cytokines through attenuation of NF-kappaB and p38 MAPK in HMC-1 human mast cell line. Inflamm. Res., v.56, n.5, p.210-215, 2007.

MONTUSCHI, P.; SALA, A.; DAHLEN, S.E.; FOLCO, G. Pharmacological modulation of the leukotriene pathway in allergic airway disease. Drug Discov. Today, v.12, n.9-10, p.404-412, 2007.

MOON, H.; CHOI, H.H.; LEE, J.Y.; MOON, H.J.; SIM, S.S.; KIM, C.J. Quercetin inhalation inhibits the asthmatic responses by exposure to aerosolized-ovalbumin in conscious guinea-pigs. Arch. Pharm. Res., v.31, n.6, p.771778,2008

MUKHERJEE, A.B.; ZHANG, Z. Allergic Asthma: Influence of Genetic and Environmental Factors. J. Biol. Chem., v.286, n.38, p.32883-32889, 2011.
NAKAMURA, T.; MATSUSHIMA, M.; HAYASHI, Y.; SHIBASAKI, M.; IMAIZUMI, K.; HASHIMOTO, N.; SHIMOKATA. K.; HASEGAWA, Y.; KAWABE, T. Attenuation of transforming growth factor- $\beta$-stimulated collagen production in fibroblasts by quercetin-induced heme oxygenase-1. Am. J. Respir. Cell. Mol. Biol., v.44, n.5, p.614-620, 2011.

NAM, N.H. Naturally occurring NF-kappa B inhibitors. Mini Rev. Med. Chem., v.6, n.8, p.945-951, 2006.

NANUA, S.; ZICK, S.M.; ANDRADE, J.E.; SAJJAN, U.S.; BURGESS, J.R.; LUKACS, N.W.; HERSHENSON, M.B. Quercetin blocks airway epithelial cell chemokine expression. Am. J. Respir. Cell. Mol. Biol., v.35, n.5, p.602$610,2006$.

NATIONAL INSTITUTES OF HEALTH. NIH. National Heart and Lung, and Blood Institute. Guidelines for the diagnosis and management of asthma. Expert Panel Report 2. Bethesda, 1997. (NIH Publication, no.9740-51). 134 p.

OKAMOTO, T. Safety of quercetin for clinical application (Review). Int. J. Mol. Med., v.16, n.2, p.275-278, 2005.

PAPIRIS, S.A.; MANALI, E.D.; KOLILEKAS, L.; TRIANTAFILLIDOU, C.; TSANGARIS, I. Acute severe asthma: new approaches to assessment and treatment. Drugs, v.69, n.17, p.2363-2391, 2009.

PARK, H.H.; LEE, S.; SON, H.Y.; PARK, S.B.; KIM, E.J.; CHOI, T.S.; SINGH, J.H.; HA, M.G.; LEE, J.E.; KIM, M.C.; HYUN, T.K.; KWON, Y.H.; KIM, S.H. Flavonoids inhibit histamine release and expression of proinflammatory cytokines in mast cells. Arch. Pharm. Res., v.31, n.10, p.1303-1311, 2008.

PARK, H.J.; LEE, C.M.; JUNG, I.D.; LEE J.S.; JEONG, Y.I.; CHANG, J.H.; CHUN, S.H.; KIM, M.J.; CHOI, I.W.; AHN, S.C.; SHIN, Y.K.; YEOM, S.R.; PARK, Y.M. Quercetin regulates Th1/Th2 balance in a murine model of asthma. Int. Immunopharmacol., v.9, n.3, p.261-267, 2009.

PEREZ-VIZCAINO, F.; DUARTE, J.; JIMENEZ, R.; SANTOS-BUELGA, C.; OSUNA, A. Antihypertensive effects of the flavonoid quercetin. Pharmacol. Rep., v.61, n.1, p.67-75, 2009.

PERRETTI, M.; FLOWER, R.J. Modulation of IL-1-induced neutrophil migration by dexamethasone and lipocortin $1 . J$. Immunol., v.150, n.3, p.992-999, 1993. 
PETERS-GOLDEN, M.; HENDERSON JR, W.R. Leukotrienes. N. Engl. J. Med., v.357, n.18, p.1841-1854, 2007.

PIETTA, P.G. Flavonoids as antioxidants - review. J. Nat. Prod., v.63, n.7, p.1035-1042, 2000.

POTTERAT, O.; HAMBURGER, M. Drug discovery and development with plant-derived compounds. Prog. Drug Res., v.65, n.45, p.47-118, 2008.

QI, L.H.; KANG, L.P.; ZHANG, J.P.; SHI, N.; ZHANG, M.; WU, T.M. Antifibrotic effects of genistein and quercetin in vitro. Yaо Хие Хие Bao, v.36, n.9, p.648-651, 2001.

RABIER,M.;DAMON,M.; CHANEZ,P.; MENCIAHUERTA, J.M.; BRAQUET, P.; BOUSQUET, J.; MICHEL, F.B.; GODARD, P. Neutrophil chemotactic activity of PAF, histamine, and neuromediators in bronchial asthma. J. Lipid Mediator, v.4, n.3, p.265-275, 1991.

RAHMAN, I.; ADCOCK, I.M. Oxidative stress and redox regulation of lung inflammation in COPD. Eur. Respir. J., v.28, n.1, p.219-242, 2006.

RAINSFORD, K.D. Anti-inflammatory drugs in the $21^{\text {st }}$ century. Subcell Biochem., v.42, p.3-27, 2007.

ROGERIO, A.P.; DORA, C.L.; ANDRADE, E.L.; CHAVES, J.S.; SILVA, L.F.; LEMOS-SENNA, E.; CALIXTO, J.B. Anti-inflammatory effect of quercetin-loaded microemulsion in the airways allergic inflammatory model in mice. Pharmacol. Res., v.61, n.4, p.288-297, 2010.

ROGERIO, A.P.; KANASHIRO, A.; FONTANARI, C.; DA SILVA, E.V.; LUCISANO-VALIM, Y.M.; SOARES, E.G.; FACIOLI, L.H. Anti-inflammatory activity of quercetin and isoquercitrin in experimental murine allergic asthma. Inflamm. Res., v.56, n.10, p.402-408, 2007.

ROGERIO, A.P.; SÁ-NUNES, A.; FACCIOLI, L.H. The activity of medicinal plants and secondary metabolites on eosinophilic inflammation. Pharmacol. Res., v.62, n.4, p.298-307, 2010.

ROMAGNANI, S. Cytokines and chemoattractants in allergic inflammation. Mol. Immunol., v.38, n.12-13, p.881-885, 2002.

ROTHENBERG, M.E.; HOGAN, S.P. The eosinophil. Annu. Rev. Immunol., v.24, p.147-174, 2006.
ROTHENBERG, M.E.; LUSTER, A.D.; LILLY, C.M.; DRAZEN, J.M.; LEDER, P. Constitutive and allergeninduced expression of eotaxin mRNA in the guinea pig lung. J Exp. Med., v.181, n.3, p.1211-1216, 1995.

SAGGINI, A.; MACCAURO, G.; TRIPODI, D.; DE LUTIIS, M.A.; CONTI, F.; FELACO, P.; FULCHERI, M.; GALZIO, R.; CARAFFA, A.; ANTINOLFI, P.; FELACO, M.; PANDOLFI, F.; SABATINO, G.; NERI, G.; SHAIKDASTHAGIRISAHEB. Y.B. Allergic inflammation: role of cytokines with special emphasis on IL-4. Int. J. Immunopathol. Pharmacol., v.24, n.2, p.305-311, 2011.

SALVI, S.S.; KRISHNA, M.T.; SAMPSON, A.P.; HOLGATE, S.T. The anti-inflammatory effects of leukotriene-modifying drugs and their use in asthma. Chest, v.119, n.5, p.15331546, 2001.

SALPETER, S.R.; ORMISTON, T.M.; SALPETER, E.E. Cardiovascular effects of beta agonists in patients with asthma and COPD: a meta-analysis. Chest, v.125, n.6, p.2309-2321, 2004.

SANDERSON, C.J.; WARREN, D.J.; STRATH, M. Identification of a lymphokine that stimulates eosinophil differentiation in vitro. Its relationship to interleukin 3 , and functional properties of eosinophils produced in cultures. $J$. Exp. Med., v.162, n.1, p.60-74, 1985.

SNEADER, W. Drug discovery: a history. West Sussex: John Wiley and Sons, 2005. $472 \mathrm{p}$.

STANCIU, L.A.; DJUKANOVIC, R. The role of ICAM-1 on T-cells in the pathogenesis of asthma. Eur. Respir. J., v.11, n.4, p.949-957, 1998.

SUR, S.; CROTTY, T.B.; KEPHART, G.M.; HYMA, B.A.; COLBY, T.V.; REED, C.E.; HUNT, L.W.; GLEICH, G.J. Sudden-onset fatal asthma. A distinct entity with few eosinophils and relatively more neutrophils in the airway submucosa? Am. Rev. Respir. Dis., v.148, n.3, p.713-719, 1993.

TILliE-LEBLOND, I.; GOSSET, P.; TONNEL, A.B. Inflammatory events in severe acute asthma. Allergy, v.60, n.1, p.23-29, 2005.

VERPOORTE, R. Exploration of nature's chemodiversity: the role of secondary metabolites as leads in drug development. Drug Discovery Today, v.3, n.5, p.232-238, 1999. 
VICENTINI, F.T.M.C.; SIMI, T.R.; DEL CIAMPO, J.O.; WOLGA, N.O.; PITOL, D.L.; IYOMASA, M.M.; BENTLEY, M.V.; FONSECA, M.J. Quercetin in w/o microemulsion: In vitro and in vivo skin penetration and efficacy against UVB-induced skin damages evaluated in vivo. Eur. J. Pharm. Biopharm., v.69, n.3, p.948-957, 2008.

WADSWORTH, T.L.; MCDONALD, T.L.; KOOP, D.R. Effects of Ginkgo biloba extract (EGb 761) and quercetin on lipopolysaccharide-induced signaling pathways involved in the release of tumor necrosis factor- $\alpha$. Biochem. Pharmacol., v.62, n.7, p.963-974, 2001.

WALLE, T.; WALLE, U.K.; HALUSHKA, P.V. Carbon dioxide is the major metabolite of quercetin in humans. J. Nutr., v.131, n.10, p.2648-2652, 2001.

WANG, Y.H.; CHAO, P.D.; HSIU, S.L.; WEN, K.C.; HOU, Y.C. Lethal quercetin-digoxin interaction in pigs. Life Sci., v.74, n.10, p.1191-1197, 2004.

WENZEL, S.E. Asthma: defining of the persistent adult phenotypes. Lancet, v.386, n.9537, p.804-813, 2006.

WORT, S.J. The management of acute severe asthma in adults. Current Anaesthesia \& Critical Care, v.14, n.2, p.81-89, 2003.
XU, B.; HE, S.S.; HAN, C.R. Inhibition of quercetin on liver fibrosis due to Schistosoma japonicum infection and on the expression of immediate early gene and metalloproteinase 1 inhibitor in liver tissue of mice. Zhongguo Ji Sheng Chong Xue Yu Ji Sheng Chong Bing Za Zhi, v.24, n.2, p.148-149, 2006.

YAMAGUCHI, Y.; SUDA, T.; SUDA J.; EGUCHI, M.; HARADA, N.; TOMINAGA, A.; TAKATSU, K. Purified interleukin 5 supports the terminal differentiation and proliferation of murine eosinophilic precursors. J. Exp. Med., v.167, n.1, p.43-56, 1988.

YING, B.; YANG, T.; SONG, X.; HU, X.; FAN, H.; LU, X.; CHEN, L.; CHENG, D.; WANG, T.; LIU, D.; XU, D.; WEI, Y.; WEN, F. Quercetin inhibits IL-1 beta-induced ICAM-1 expression in pulmonary epithelial cell line A549 through the MAPK pathways. Mol. Biol. Rep., v.36, n.6, p.1825-1832, 2009.

ZIMMERMANN, N.; HERSHEY, G.K.; FOSTER, P.S.; ROTHENBERG, M.E. Chemokines in asthma: cooperative interaction between chemokines and IL-13. J Allergy Clin. Immunol., v.111, n.2, p.227-242, 2003.

Received for publication on 23 ${ }^{\text {rd }}$ May 2012 Accepted for publication on $15^{\text {th }}$ October 2012 